Ne'am F Agha ${ }^{1}$

BDS, MSc (Asst Prof)

Zeina M Ahmad ${ }^{2}$ BDS, MSc (Lec)

Zaid B Al-Dewachi ${ }^{1}$ BDS, MSc (Lec)

\section{Correlation of Incisors Inclination and Position with Facial Profile}

\author{
1Dept of Pedod, Orthod and Prev Dentistry \\ College of Dentistry, University of Mosul \\ 2Department of Prosthetic Dentistry \\ College of Dentistry, University of Mosul
}

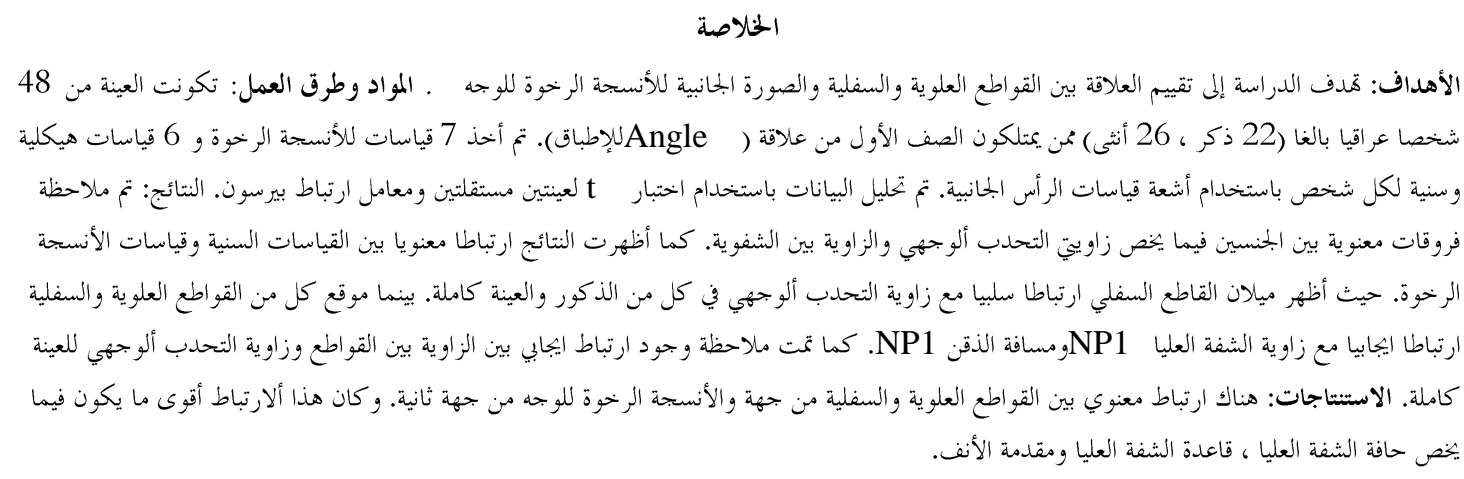

ABSTRACT

Aims: This study aimed to assess the relationship between upper and lower incisors and soft tissue facial profile. Materials and methods: The sample included forty eight Iraqi adults (22 men, 26 women) with Class I normal occlusion. Seven soft tissue parameters and six skeletal and incisal parameters were measured on lateral cephalometric radiographs. The data were analyzed using independent sample $t$ test and Pearson correlation analysis. Results: sexual dimorphism was reported only for soft tissue convexity angle and interlabial angle. The results also showed correlation between incisor parameters and soft tissue parameters. Lower incisor inclination showed negative correlation with soft tissue profile angle for male and total samples. While both upper and lower incisors positions showed positive correlation with upper lip/NP angle and soft tissue pogonion/NP distance. Positive correlation was noticed between interincisal angle and soft tissue profile convexity angle for the total sample. Conclusions: upper and lower incisors are correlated to the overlying soft tissue structures. This correlation was mostly significant for the upper lip vermilion, upper lip base and tip of the nose.

Key words: Incisor inclination, Incisor position, Facial profile.

Agha NF, Ahmad ZM, Al-Dewachi ZB. Correlation of Incisors Inclination and Position with Facial Profile. Al-Rafidain Dent J. 2011; 11(1):154-160.

Received: 22/12/2009 Sent to Referees: 24/12/2009 Accepted for Publication: 23/2/2010

\section{INTRODUCTION}

A substantial body of science is available to augment the clinician's subjective assessment of facial harmony and beauty in all clinical disciplines involved with enhancement of facial esthetics including esthetic dentistry, orthognathic surgery, orthodontics and prosthodontics ${ }^{(1)}$. The position of the incisors is taken as a key landmark in treatment planning in order to provide the patient with the most attractive and well balanced smile ${ }^{(2)}$. The profile form of the patient face is often representative of the inclination of anterior teeth ${ }^{(3)}$, and clinicians should align incisor positions ideally to obtain good facial balance following treatment taking into consideration the great variability in soft tissue thickness between individuals ${ }^{(4)}$. Therefore it is important to quantify the relationship between anteroposterior position of incisors to overlying soft tissue structures Andrews $^{(5)}$ found that the position of maxillary central incisors are strongly correlated with forehead inclination in adult white female subjects and stated that treatment goals should include a harmonious anteroposterior relationship between maxillary 
central incisor and forehead. Tanikawa et $a l .,{ }^{(6)}$ examined the morphologic characteristics of dentoskeletal pattern in different lip vermilion profile shapes and reported a correlation between the horizontal position and labiolingual inclination of upper and lower incisors to the lip vermilion profile configuration.

This study aimed to 1 . Evaluate the relationship of maxillary and mandibular central incisors inclination and position to the overlying soft tissue profile structures in a sample of adults with Class I normal occlusion. 2. To explore differences in these measurements between males and females.

MATERIALS AND METHODS

Forty eight Iraqi adults (22 males and 26 females) aged 18-25 years comprised the sample used in this study. Inclusion criteria were Class I normal occlusion with minor or no crowding, normal overjet and overbite, good facial harmony in profile with competent lips ${ }^{(4)}$, and no previous orthodontic treatment. All radiographs were taken using SS White cephalometric machine with the cephalostat oriented to the Frankfort horizontal plane the teeth were in maximum intercuspation and the lips in contact. All radiograph were traced and measured manually by one investigator. 12 angular and 3 linear measurements were recorded on each tracing. The nasion perpendicular (NP) was established by dropping a line inferiorly from nasion perpendicular to the Frankfort horizontal line and this line was used as a reference line for most of the measurements ${ }^{(7)}$.

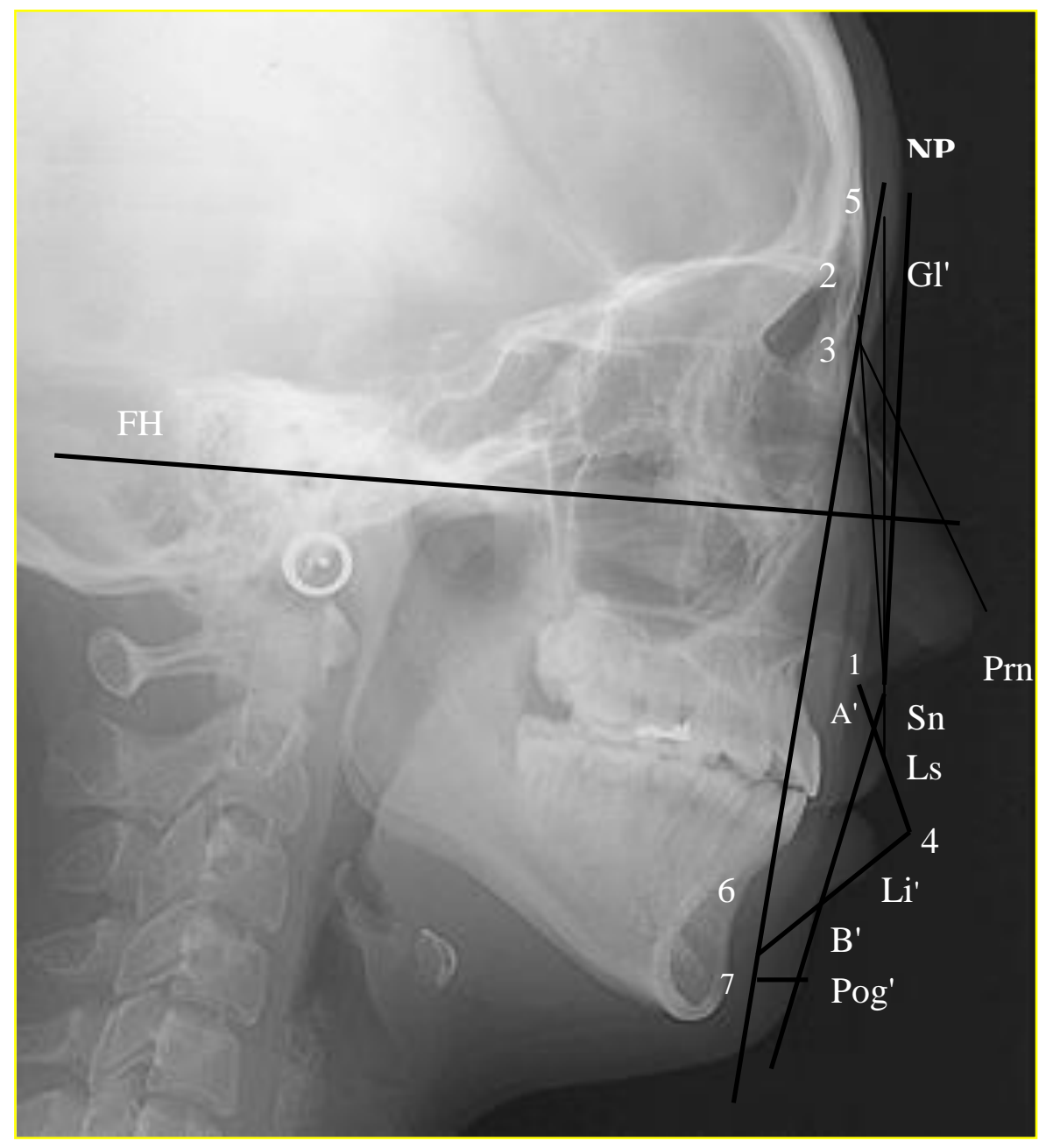

Figure (1): soft tissue variables. A: 1 . Soft tissue convexity angle; 2 . Pronasal/NP angle; 3. Subnasal/ NP angle; 4. Interlabial angle; 5 . Upper lip/NP angle; 6. Lower sulcus angle; 7 . Soft tissue pogonion $/ \mathrm{NP}$ distance. $\mathrm{FH}=$ Frankfort horizontal plane; NP= nasion perpendicular. 
The following variables were used to assess the soft tissue facial profile (Figure 1):

1. Soft tissue convexity angle (Gl'-Sn-Pog'): the angle formed by intersection of a line from soft tissue glabella to subnasal and a line from subnasal to soft tissue pogonion $^{(8)}$.

2. Pronasal/NP angle: the angle formed by intersection of a line passing from soft tissue nasion to pronasal and NP line ${ }^{(9)}$.

3. Subnasal/ NP angle: the angle formed between NP and a line drawn from subnasal to soft tissue nasion ${ }^{(9)}$.

4. Interlabial angle (ILA): the intersection of a line drawn from soft tissue point $\mathrm{A}$ and upper vermilion border and a line from lower vermilion border to soft tissue point $\mathrm{B}^{(10)}$.

5. Upper lip/NP angle: the angle formed at intersection of $\mathrm{NP}$ with a line passing from labrale superius (Ls) to soft tissue nasion $^{(9)}$.

6. Lower sulcus angle (LSA): measured at the intersection of NP and a line from labrale inferius (Li) and soft tissue point

$$
\mathrm{B}^{(9)} \text {. }
$$

7. The distance from soft tissue pogonion $\left(\mathrm{Pog}^{\prime}\right)$ to NP line measured perpendicular to NP line. This distance was recorded as positive when Pog' was ahead of NP line, as negative when Pog' was behind the line and as zero when it was on the plane.

The skeletal and dental measurements included (Figure 2): 1. Skeletal convexity angle $(\mathrm{N}-\mathrm{A}-\mathrm{Pog})^{(11)}$. 2. Maxillary incisor to palatal plane angle (U1/PP) ${ }^{(12)}$. 3. Mandibular incisor to mandibular plane angle $(\mathrm{L} 1 / \mathrm{MP})^{(11)}$. 4. Interincisal angle (U1/L1): is measured between upper and lower incisors long axis lines ${ }^{(11)} .5$. Maxillary incisor to NP distance. 6. Mandibular incisor to NP distance. These distances were measured perpendicular to the reference line and were recorded as positive when incisal edge was ahead of NP line, as negative when incisal edge was behind the line and as zero when it was on the plane.

Descriptive statistics, independent samples $t$-test, and Pearson correlation tests were performed using SPSS software package (version 11.5).

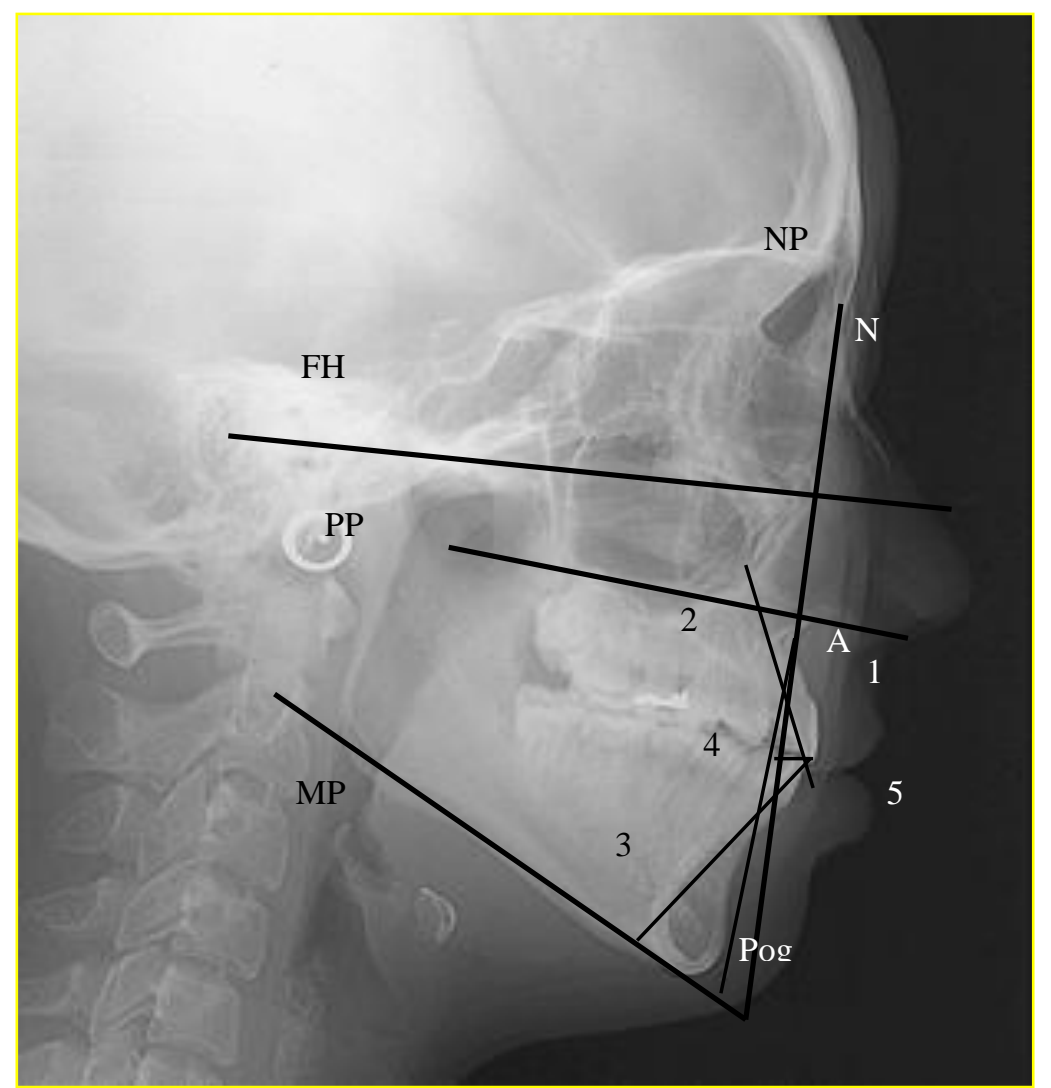

Figure (2): Dental parameters; 1 . Skeletal convexity angle; 2.Upper incisor/PP angle; 3.Lower incisor/MP angle; 4. Interincisal angle; 5.upper/ lower incisor/ NP distance. $\mathrm{FH}=$ Frankfort horizontal plane; $\mathrm{NP}=$ nasion perpendicular; $\mathrm{PP}=$ palatal plane; $\mathrm{MP}=$ mandibular plane. 


\section{RESULTS}

Table (1) shows the minimum, maximum and mean values of the $13 \mathrm{va}-$ riables. Table (2) demonstrates the results of independent samples $t$-test. Only the soft tissue convexity angle and interlabial angle showed significant difference between the sexes at the level $p \leq 0.05$ and $p \leq 0.01$ respectively where males showed higher value than females for soft tissue convexity angle, while females presented higher value for interlabial angle.

Table (1): Descriptive statistics for the total sample.

\begin{tabular}{cccccc}
\hline Variable & No. & Minimum & Maximum & Mean & $\underline{\mathbf{+ S D}}$ \\
\hline Facial profile angle & 48 & 157 & 178 & 167.77 & 4.89 \\
Prn/NP angle & 48 & 13 & 39 & 29.00 & 4.33 \\
Sn/NP angle & 48 & 5 & 25 & 10.91 & 3.80 \\
Interlabial angle & 48 & 82 & 142 & 113.02 & 12.64 \\
Upper lip/NP angle & 48 & 7 & 21 & 13.75 & 3.02 \\
Lower lip/NP angle & 48 & 15 & 65 & 41.85 & 9.70 \\
Pog' to NP distance & 48 & -3 & 25 & 10.27 & 6.15 \\
$\begin{array}{c}\text { Skeletal profile con- } \\
\text { vexity angle }\end{array}$ & 48 & 164 & 188 & 175.91 & 5.83 \\
U1/ palatal plane & 48 & 83 & 124 & 112.00 & 7.00 \\
$\quad$ angle & & & & & \\
L1/ mandibular & 48 & 82 & 109 & 96.12 & 6.56 \\
$\quad$ plane angle & 48 & 110 & 148 & 129.56 & 9.07 \\
Interincisal angle & 48 & -7.50 & 14 & 4.36 & 4.37 \\
U1to NP distance & 48 & -10 & 12 & 1.64 & 4.12 \\
\hline L1to NP distance & 48
\end{tabular}

$\mathrm{NO}=$ number; $\mathrm{SD}=$ standard deviation

Table (2): Comparison of variables between male and female samples.

\begin{tabular}{|c|c|c|c|c|c|c|}
\hline Variable & Gender & No. & Mean & \pm SD & $t$-test & $p$-value \\
\hline \multirow{2}{*}{$\begin{array}{c}\text { Facial profile } \\
\text { angle }\end{array}$} & male & 22 & 169.54 & 4.71 & 2.43 & $.019 *$ \\
\hline & female & 26 & 166.26 & 4.60 & & \\
\hline \multirow{2}{*}{ Prn/NP angle } & male & 22 & 28.95 & 3.82 & -.06 & .948 \\
\hline & female & 26 & 29.03 & 4.79 & & \\
\hline \multirow{2}{*}{ Sn/NP angle } & male & 22 & 11.77 & 4.36 & 1.44 & .154 \\
\hline & female & 26 & 10.19 & 3.17 & & \\
\hline \multirow{2}{*}{ Interlabial angle } & male & 22 & 106.68 & 12.76 & -3.57 & $.001 * *$ \\
\hline & female & 26 & 118.38 & 9.93 & & \\
\hline \multirow{2}{*}{$\begin{array}{c}\text { Upper lip/NP } \\
\text { angle }\end{array}$} & male & 22 & 14.36 & 2.62 & 1.30 & .199 \\
\hline & female & 26 & 13.23 & 3.27 & & \\
\hline \multirow{2}{*}{$\begin{array}{c}\text { Lower lip/NP } \\
\text { angle }\end{array}$} & male & 22 & 42.42 & 10.44 & .36 & .718 \\
\hline & female & 26 & 41.38 & 9.25 & & \\
\hline \multirow{2}{*}{ Pog' /NP distance } & male & 22 & 11.77 & 5.47 & 1.58 & .121 \\
\hline & female & 26 & 9.00 & 6.50 & & \\
\hline \multirow{2}{*}{ N-A-Pog angle } & male & 22 & 177.31 & 6.41 & 1.55 & .127 \\
\hline & female & 26 & 174.73 & 5.12 & & \\
\hline \multirow{2}{*}{ U1/PP angle } & male & 22 & 112.68 & 6.59 & .61 & .541 \\
\hline & female & 26 & 111.42 & 7.41 & & \\
\hline \multirow{2}{*}{ L1/MP angle } & male & 22 & 95.18 & 6.99 & -.91 & .365 \\
\hline & female & 26 & 96.92 & 6.19 & & \\
\hline \multirow{2}{*}{ Interincisal angle } & male & 22 & 131.72 & 8.40 & 1.54 & .130 \\
\hline & female & 26 & 127. & 9.37 & & \\
\hline \multirow{2}{*}{ U1to NP distance } & male & 22 & 4.22 & 4.25 & -.19 & .844 \\
\hline & female & 26 & 4.48 & 4.55 & & \\
\hline \multirow{2}{*}{ L1to NP distance } & male & 22 & 1.43 & 3.76 & 32 & 074 \\
\hline & female & 26 & 1.82 & 4.47 & -.32 & 0.14 \\
\hline
\end{tabular}

$\mathrm{No}=$ number; $\mathrm{SD}=$ standard deviation; * significant at $p \leq 0.05 ; * *$ significant at $p \leq 0.01$. 
Correlation coefficients of dental parameters with soft tissue variables for males, females and the total sample are displayed in Table (3). L1/MP angle showed negative correlation with soft tissue convexity angle for males and the total sample, it also showed negative correlation with upper lip/NP angle for males at $p \leq 0.05$. Interincisal angle demonstrated positive correlation with soft tissue convexity angle for the total sample and with Pog'/NP distance for male sample. Both upper and lower incisor distances to NP line showed positive correlation with upper lip/NP angle and $\mathrm{Pog}^{\prime} / \mathrm{NP}$ distance in males, females and the total sample at $p \leq 0.01$. They also showed positive correlation with pronasal/NP angle for males and total sample with subnasal/NP angle for female and total samples.

The skeletal convexity angle showed positive correlation with soft tissue convexity angle at the level $p \leq 0.01$ for males and total sample and at the level $p \leq 0.05$ for female sample.

Table (3): Correlation of incisal parameters with soft tissue parameters.

\begin{tabular}{ccccccccc}
\hline \multirow{2}{*}{ Variable } & Sample & Gl'-Sn-Pog' & $\begin{array}{c}\text { Pronasal } \\
\text { /NP }\end{array}$ & $\begin{array}{c}\text { Subnas- } \\
\text { al/NP }\end{array}$ & ILA & $\begin{array}{c}\text { Upper } \\
\text { lip/NP }\end{array}$ & LSA & Pog'/NP \\
\hline \multirow{2}{*}{ N-A-Pog } & Total & $0.557^{* *}$ & -0.223 & -0.259 & 0.01 & -0.177 & -0.225 & 0.049 \\
& Male & $0.600^{* *}$ & -0.081 & -0.394 & 0.087 & -0.208 & -0.208 & -0.091 \\
& Female & $0.451^{*}$ & -0.359 & -0.215 & 0.194 & -0.258 & -0.294 & 0.076 \\
\hline \multirow{2}{*}{ UI/PP } & Total & 0.127 & .081 & 0.000 & -0.158 & 0.247 & -0.08 & 0.252 \\
& Male & 0.142 & 0.062 & -0.034 & -0.207 & -0.012 & -0.075 & 0.006 \\
& Female & 0.074 & 0.095 & -0.005 & -0.064 & 0.384 & -0.097 & 0.385 \\
\hline \multirow{2}{*}{ LI/MP } & Total & $-0.379^{* *}$ & -0.002 & -0.011 & -0.025 & -0.241 & 0.259 & -0.266 \\
& Male & $-0.492^{*}$ & -0.171 & -0.039 & 0.002 & $-0.473^{*}$ & 0.285 & -0.416 \\
& Female & -0.228 & 0.123 & 0.090 & -0.222 & -0.037 & 0.249 & -0.111 \\
\hline \multirow{3}{*}{ U1/L1 } & Total & $0.293^{*}$ & -0.076 & 0.129 & 0.131 & 0.070 & -0.243 & 0.253 \\
& Male & 0.317 & 0.201 & 0.187 & 0.206 & 0.414 & -0.236 & $0.440^{*}$ \\
& Female & 0.178 & -0.242 & -0.012 & 0.334 & -0.204 & -0.282 & 0.070 \\
\hline \multirow{2}{*}{ U1-NP } & Total & 0.005 & $0.395^{* *}$ & $0.347 *$ & -0.111 & $0.825^{* *}$ & -0.222 & $0.747^{* *}$ \\
& Male & 0.068 & $0.434^{*}$ & 0.294 & -0.102 & $0.873^{* *}$ & -0.275 & $0.829^{* *}$ \\
& Female & -0.026 & 0.372 & $0.448^{*}$ & -0.183 & $0.833^{* *}$ & -0.175 & $0.741^{* *}$ \\
\hline \multirow{2}{*}{ L1-NP } & Total & 0.033 & $0.429^{* *}$ & $0.322^{*}$ & -0.124 & $0.822^{* *}$ & -0.225 & $0.767^{* *}$ \\
& Male & 0.064 & $0.507^{*}$ & 0.297 & -0.161 & $0.806^{* *}$ & -0.252 & $0.817^{* *}$ \\
& Female & 0.044 & 0.385 & $0.401^{*}$ & -0.176 & $0.871^{* *}$ & -0.023 & $0.789^{* *}$ \\
\hline
\end{tabular}

* Significant at 0.05 level; ** significant at 0.01 level.

\section{DISCUSSION}

This study investigated the relationship of upper and lower incisors to overlying facial structures in a sample of Class I occlusion adults, the sample included both male and female subjects and comparison between the sexes showed significant difference for two variables. Males showed significantly higher soft tissue convexity angle indicating a straighter profile in males, and this comes in agreement with the findings reported for Suadis ${ }^{(13)}$ and European Caucasians ${ }^{(14)}$. On the other hand, females showed significantly larger inter- labial angle indicating less lip projection in females; this may be attributed to the fact that males have thicker lips as have been demonstrated in a previous study on Iraqi adults ${ }^{(15)}$.

Correlation test between soft tissue parameters and skeletal parameters revealed significant positive correlation between soft tissue convexity angle and the skeletal convexity angle, which indicates that a straight soft tissue profile is mostly a reflection of an underlying orthognathic skeletal configuiration. Significant negative correlation was reported between lower incisor inclination and the 
angle of soft tissue convexity in total sample and in male sample. This indicates that subjects with straight facial profile tend to have upright incisors. The interincisal angle showed positive correlation with soft tissue convexity angle for the total sample which comes in agreement with the findings of Akiko et al., ${ }^{(16)}$ who reported that as the interincisal angle decreases the upper lip moves forward and the lower lip and inferior sulcus moves backwards that is to say the facial profile becomes more convex. Which, again indicates that as the interincisal angle increases i,e the incisors are more upright; the facial profile becomes straighter.

Both upper and lower incisors positions showed significant positive correlation with four soft tissue parameters. Thus patients with protruded upper and lower incisors could be expected to have a protruded nose and subnasal point, a prominent upper lip and a protruded soft tissue chin. Similar findings for correlation of incisors position with the upper lip profile were reported for Japanese ${ }^{(6)}$ and Caucasians ${ }^{(17,18)}$. On the other hand, the lower lip (represented by lower sulcus angle) showed no correlation with neither incisor inclination nor position. The findings of this study indicates that mid face structures (including nose and upper lip) have stronger correlation with the underlying hard tissues than the lower lip, which disagree with the findings of other researchers ${ }^{(19-21)}$ who reported that soft to hard tissue relationships were consistently stronger for the lower lip than for upper lip. This conflict may be related to variation in the variable used to assess the lower lip between the present study and those mentioned earlier.

\section{CONCLUSIONS}

Upper and lower incisors position rather than inclination have a strong correlation with the mid facial structures and soft tissue chin. while, the lower lip showed no correlation with any of the dental parameters indicating that upper and lower incisors play a less significant role in the configuration of lower lip.

\section{REFERENCES}

1. Keim RJ. Achieving facial harmony through orthodontics. J Calif Dent Assoc. 2002; 29: 129-135.

2. Bass NM. Measurement of the profile angle and the esthetic analysis of the facial profile. J Orthod. 2003; 30(1): 3-9.

3. Hicky JC, Zarb GA, Bolender CL. Boucher's prosthodontic treatment for edentulous patients. $9^{\text {th }}$ ed. CV Mosby. 1985 P: 373.

4. Loi H, Nakata S, Nakisama A, Counts A. Effects of facial convexity on A-P lip position of the most favoured Japanese facial profiles. Angle Orthod. 2005; 75(3): 326-332.

5. Andrews WA. AP relationship of the maxillary central incisors to the forehead in adult white females. Angle Ortshod. 2008; 78(4): 662-669.

6. Tanikawa C, Nakamura K, Yagi M, Takada K. Lip vermilion profile patterns and corresponding dentoskeletal forms in female adults. Angle Orthod. 2009; 9(5): 849-858.

7. McNamara JR Jr. A method of cephalometric evaluation. Am J Orthod. 1984; 86(12): 449-469.

8. Legan HL, Burstone CJ. Soft tissue cephalometric analysis for orthognathic surgery. J Oral Surg. 1980; 38: 744751.

9. Hwang HS, Kim WS, McNamara JR Jr. A comparative study of two methods of quantifying the soft tissue profile. Angle Orthod. 2000; 70(3): 200-207.

10. Sutter RE Jr, Turley PK. Soft tissue evaluation of contemporary Caucasian and African American female facial profiles. Am J Orthod Dentofacial Orthop. 1998; (6): 487-496.

11. Downs WB. Variations in facial relationships: their significance in treatment and prognosis. Am J Orthod. 1948; 34:811-840.

12. Bishara SE, Fernandez AG. Cephalometric comparisons of the dental facial relationships of two adolescent populations from Iowa and Northern Mexico. Am J Orthod. 1985; 88: 314-322.

13. Hashim HA, AL Barakati SF. Cephalometric soft tissue profile analysis between two different ethnic groups: A comparative study. J Contemp Dent Prac. 2003; 4(2): 60-73. 
14. Fernandez-Riveiro P, Smyth-Chmosa E, Suarez-Quintanilla D, SuarezCunqueiro M. Angular phtogrametyric analysis of the soft tissue facial profile. Eur J Orthod. 2003; 25: 393-399.

15. Abdul-Kader MY, Al-Dawoody AD, Agha NF. Evaluation of Holdaway soft tissue analysis for Iraqi adults with Class I normal occlusion. Rafidain Dent J. 2008; 8(2):

16. Akiki Y, Sachio T, Yutaka H, Hiroyuki I. Relationship between hard tissue and soft tissue changes in surgical orthodontic treatment. Orthod Waves Jpn Ed. 2004; 63(2): 85-94.

17. Rains MD, Nanda R. Soft tissue changes associated with maxillary incisor retraction. Am J Orthod. 1982; 81(6): 481-488.

18. Kokodynski RA, Marshal SD, Ayer W, Weintraub NH, Hoffman DL. Profile changes associated with maxillary incisor retraction in the post adolescent orthodontic patients. Int $J$ Adult Orthod Orthognath Surg. 1997; 12: 129-134.

19. Caplan MJ, Kivapuja PK. The effect of premolar extractions on the soft tissue profile in adult African American females. Angle Orthod. 1997; 67(2): 129136.

20. Moseling KP, Woods MG. Lip curve changes in females with premolar extraction or non extraction treatment. Angle Orthod. 2004; 74(1): 51-62.

21. Hodges A, Rossouw PE, Campbell PM, Boley JC, Alexander RA, Buschang PH. Prediction of lip response to four first premolar extractions in white female adolescents and adults. Angle Orthod. 2009; 79(3): 413-421. 